\title{
Base-resolution maps of 5-formylcytosine and 5-carboxylcytosine reveal genome-wide DNA demethylation dynamics
}

Cell Research (2015) 25:386-389. doi:10.1038/cr.2015.5; published online 16 January 2015

\section{Dear Editor,}

The TET family of dioxygenases can oxidize 5-methylcytosine $(5 \mathrm{mC})$ to 5 -hydroxymethylcytosine $(5 \mathrm{hmC})$, 5 -formylcytosine (5fC), and 5-carboxylcytosine $(5 \mathrm{caC})$ in mammalian genomic DNA via a stepwise manner [15]. $5 \mathrm{fC}$ and $5 \mathrm{caC}$ are selectively recognized and excised by mammalian thymine DNA glycosylase (TDG), and restored to normal cytosine through base excision repair $[3,6-9]$. Once converted to $5 \mathrm{fC}$ and $5 \mathrm{caC}$, the modified cytosine base is presumably committed to demethylation through the TDG-dependent pathway or other potential mechanisms. Thus $5 \mathrm{fC}$ and $5 \mathrm{caC}$ specifically mark active demethylation in the mammalian genome.

To better understand the Tet/Tdg-mediated $5 \mathrm{mC}$ oxidation and demethylation, we and others have developed profiling methods for $5 \mathrm{fC}$ and/or $5 \mathrm{caC}$, in mouse ESCs [10-12]. These studies revealed the preferential occurrence of $5 \mathrm{fC}$ and $5 \mathrm{caC}$ at low-methylated regions, active enhancers, and pluripotency TF-binding sites. However, whether and how $5 \mathrm{fC}$ and $5 \mathrm{caC}$ possess unique features associated with active demethylation, active enhancers and functional genomic elements are still unclear. Genome-wide, single-base resolution maps of $5 \mathrm{fC}$ and $5 \mathrm{caC}$ are required to reveal their roles in genome-wide DNA demethylation dynamics as well as their distinct properties.

We have demonstrated that chemical modification-assisted bisulfite sequencing (CAB-seq) can detect the base-resolution information of $5 \mathrm{fC}$ and $5 \mathrm{caC}[10,13]$. However, due to their low abundance, a direct, whole-genome bisulfite sequencing is impractical. We present here a pre-enrichment-based bisulfite sequencing strategy, or DNA immunoprecipitation-coupled CAB-seq (DIPCAB-seq; Figure 1A and Supplementary information, Figure S1A), to generate the genome-wide, single-base resolution maps for $5 \mathrm{fC}$ and $5 \mathrm{caC}[10,13,14]$.

We first confirmed that this approach can effectively amplify and detect $5 \mathrm{fC}$ and $5 \mathrm{caC}$ signals on model DNA at single-base resolution (Supplementary information, Figure S1B-S1E). Sanger sequencing showed a high protection rate of CAB-seq from deamination (Supplementary information, Figure S1D); the overall signal is increased from $5 \%$ to $50 \%$ on the model DNA (Supplementary information, Figure S1E). The protection rate of $5 \mathrm{fC}$ by $\mathrm{EtONH}_{2}$ is similar to that by the $\mathrm{NaBH}_{4}$-mediated reduction reported by us [10] and in redBS [14] (Supplementary information, Figure S1F-S1H).

Using the DIP-CAB-seq approach, we generated both profiling and single-base resolution maps of $5 \mathrm{fC}$ and $5 \mathrm{caC}$ in $T d g^{A / f}$ and $T d g^{-/-}$mouse ESCs with more than $65 \%$ mapping efficiency (Supplementary information, Table S1). The profiling analysis indicated that both $5 \mathrm{fC}$ and $5 \mathrm{caC}$ accumulate at enhancer regions in $T d g^{-/}$mouse ESCs as well as major satellite repeats in both $T d g^{A / f}$ and $\mathrm{Td}^{-/-}$mouse ESCs, which is consistent with previous findings $[10,11]$ (Supplementary information, Figure S1I-S1J). A substantial increase of $5 \mathrm{caC}$ signals but not $5 \mathrm{fC}$ at promoter regions with $T d g$ knockout was also observed (Figure 1B), indicating distinct features of $5 \mathrm{fC}$ and $5 \mathrm{caC}$ in the mammalian epigenome.

We next analyzed $5 \mathrm{fC}$ - and $5 \mathrm{caC}$-enriched regions using the base-resolution data (Supplementary information, Figure $\mathrm{S} 1 \mathrm{~K}$ ). We determined that $5 \mathrm{fC}$ and $5 \mathrm{caC}$ signals are significantly increased in $T d g^{-/-}$mouse ESCs compared to wild-type mouse ESCs (Supplementary information, Figure S1L). We observed $72135 \mathrm{fC}$ sites and $48065 \mathrm{caC}$ sites $(P<0.05)$, with only $6.53 \%(n=314)$ overlapping with each other (Figure 1C). Consistent with the profiling results, a major portion of $5 \mathrm{fC}$ and $5 \mathrm{caC}$ sites are located in intragenic regions, especially in coding exons and introns (Figure 1D). A fraction of $5 \mathrm{fC}$ and $5 \mathrm{caC}$ sites reside in $5^{\prime} \mathrm{UTR}, 3^{\prime} \mathrm{UTR}$, promoters and TTS regions. Notably, $5 \mathrm{fC}$ occurs more frequently in exons, promoter regions, and less frequently in intron regions than $5 \mathrm{caC}$ (Figure 1D). These results reveal that $5 \mathrm{fC}$ and $5 \mathrm{caC}$ may mark or represent distinct $5 \mathrm{mC}$ and $5 \mathrm{hmC}$ oxidation sites, which may have functional implications. 
A

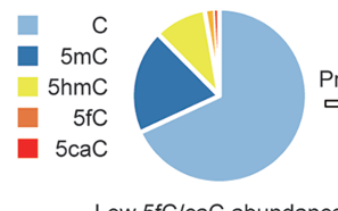

Low $5 \mathrm{fC} / \mathrm{caC}$ abundance

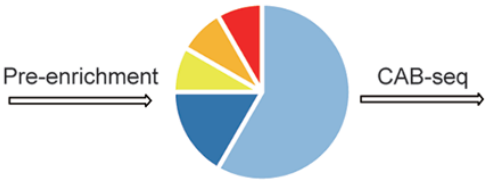

Enhanced abundance

B

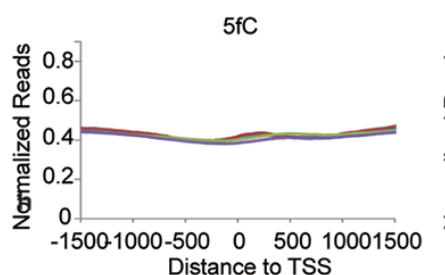

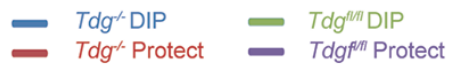
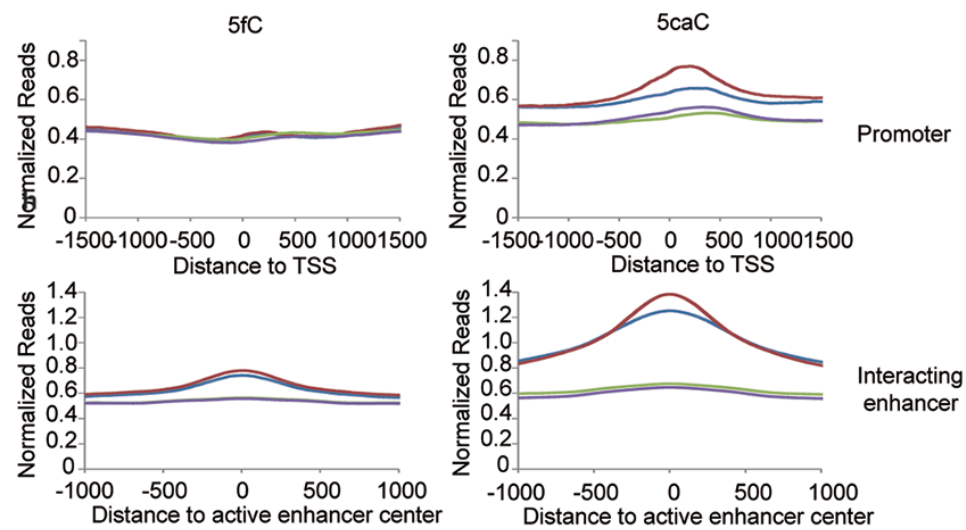

E
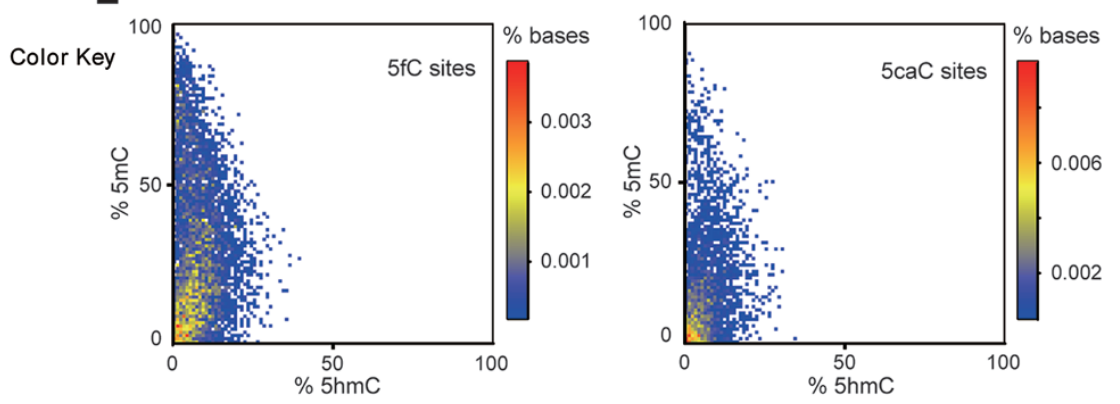

I

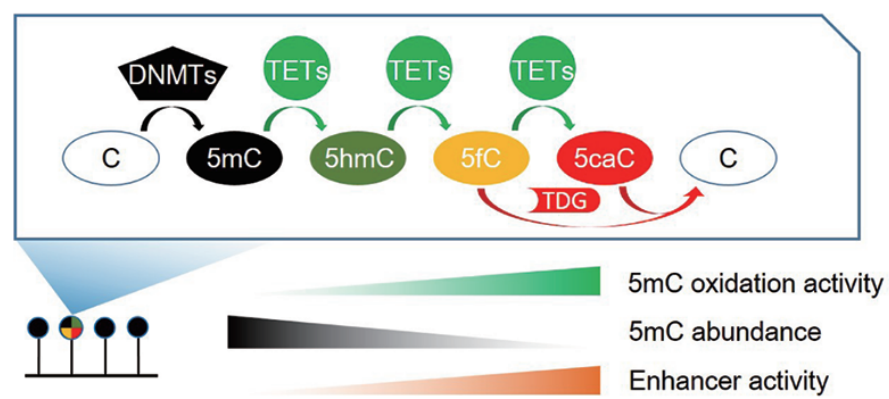

C

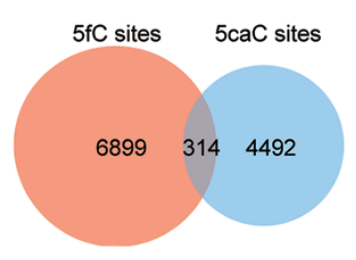

D

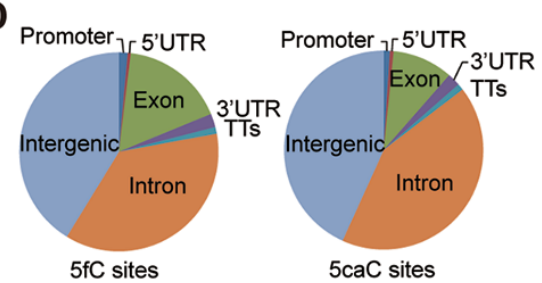

F

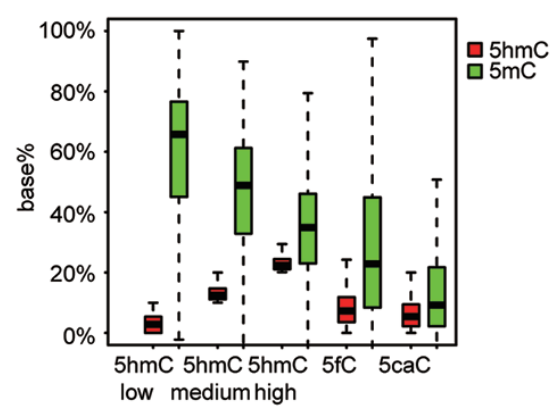

G
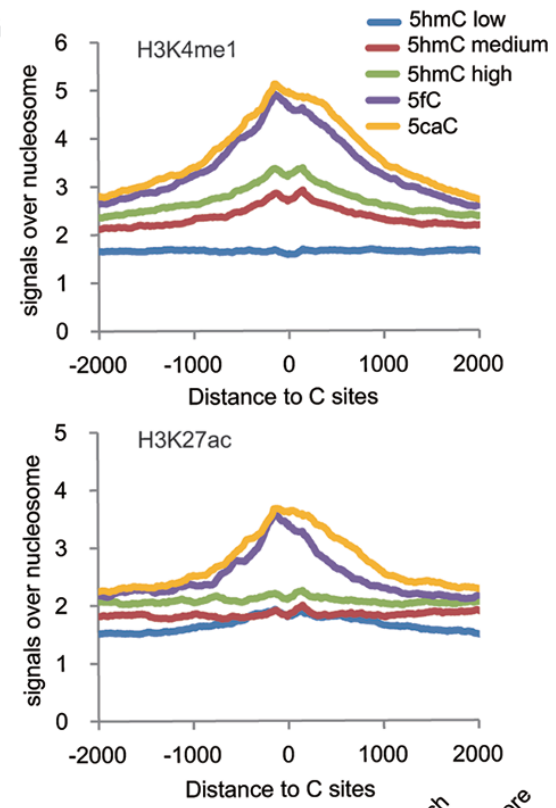

H

ACAGTA Hif1a 0.76 1e-140

TCAAGGTCAC Esrrb 0.97 1e-124

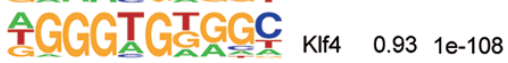

ATTTGCATANA Oct4 0.93 1e-87

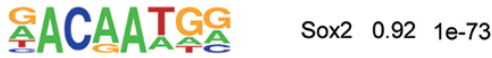


Figure 1 (A) DNA immunoprecipitation-coupled chemical modification-assisted bisulfite sequencing of $5 f C$ and $5 \mathrm{caC}$ in genomic DNA. The $5 \mathrm{fC}$ and $5 \mathrm{caC}$ signals are amplified and detected by CAB-seq following pre-enrichment. (B-D) Generation, annotation and comparison of genome-wide profiling and base-resolution maps of $5 \mathrm{fC}$ and $5 \mathrm{caC}$. The distribution of $5 \mathrm{fC}$ and $5 \mathrm{caC}$ signals in $T d g^{\mathrm{flft}}$ and $\mathrm{Tdg}{ }^{-/}$ mouse ES cells at the promoter and interacting enhancer regions, respectively (B). Venn diagram presentation of the number of $5 \mathrm{fC}$ and $5 \mathrm{caC}$ sites, and their overlap (C). Pie chart showing the overall distribution of $5 \mathrm{fC}$ and $5 \mathrm{caC}$ sites in genomic elements (D). (EI) The $5 \mathrm{mC}$ oxidation activity correlates with the extent of DNA hypomethylation and enhancer activity. Heatmaps of $5 \mathrm{hmC}$ and $5 \mathrm{mC}$ percentages at $5 \mathrm{fC}$ and $5 \mathrm{caC}$ sites. The occupancies of $5 \mathrm{hmC}$ and $5 \mathrm{mC}$ were estimated based on TAB-seq and traditional bisulfite sequencing data (E). The levels of $5 \mathrm{hmC}$ and $5 \mathrm{mC}$ in several groups of modified cytosines enriched with $5 \mathrm{hmC}, 5 \mathrm{fC}$ and $5 \mathrm{caC}$. $5 \mathrm{hmC}$ sites were further divided into low $(0 \%-10 \%)$, medium $(10 \%-20 \%)$, high $(>20 \%)$ subgroups $(5000$ sites were randomly selected for each subgroup) (F). The distribution of H3K4me1 and H3K27ac signals at each modified cytosine groups. ChIP-seq signals were divided by nucleosome-seq signals (G). De novo motif analysis by HOMER [15] at \pm 100 bp region around $5 \mathrm{caC}$ sites (H). Schematic diagram illustrating the dynamic equilibrium between DNMT-based cytosine methylation and Tet/Tdg-mediated $5 \mathrm{mC}$ oxidation and active demethylation. A gradient of $5 \mathrm{mC}$ oxidation activity to $5 \mathrm{hmC}, 5 \mathrm{fC}$ and $5 \mathrm{caC}$, correlates with decreased DNA methylation level and increased enhancer activity at regulatory elements (I).

By combining the single-base resolution $5 \mathrm{fC}$ and $5 \mathrm{caC}$ maps with $5 \mathrm{mC}$ and $5 \mathrm{hmC}$ maps, we plotted the percentages of $5 \mathrm{mC}$ and $5 \mathrm{hmC}$ at each $5 \mathrm{fC}$ and $5 \mathrm{caC}$ sites, respectively (Figure 1E). The abundance of $5 \mathrm{mC}$ notably decreases at $5 \mathrm{caC}$ sites compared to $5 \mathrm{fC}$ sites, associating the Tet-mediated $5 \mathrm{mC}$ oxidation with hypomethylated regions. We then sectionalized the Tet oxidation level by dividing the $5 \mathrm{hmC}$ sites into three sets with low (0\%-10\%), medium (10\%-20\%) and high ( > $20 \%$ ) $5 \mathrm{hmC}$ percentage (Figure $1 \mathrm{~F}$ ). The median $5 \mathrm{mC}$ abundance gradually decreases from $65.75 \%$ to $34.92 \%$, accompanied by the increase of $5 \mathrm{hmC}$ abundance and the appearance of $5 \mathrm{fC}$ and $5 \mathrm{caC}$ sites, suggesting that lower methylated regions correlate with higher demethylation activities. Although the decrease of the $5 \mathrm{mC}$ and $5 \mathrm{hmC}$ abundance in $5 \mathrm{fC}$-marked regions has been noticed [10, 11], our single-base resolution analysis demonstrated the close correlation between the extent of hypomethylation and $5 \mathrm{mC}$ oxidation.

To further characterize $5 \mathrm{fC}$ and $5 \mathrm{caC}$ sites, we calculated the ChIP-seq signals of enhancer histone modification markers at these regions (Figure $1 \mathrm{G}$ ). We observed higher $\mathrm{H} 3 \mathrm{~K} 4 \mathrm{me} 1$ signals at $5 \mathrm{fC}$ sites and even higher at $5 \mathrm{caC}$ sites when compared to $5 \mathrm{hmC}$ sites. In comparison, $\mathrm{H} 3 \mathrm{~K} 27 \mathrm{ac}$, the active enhancer marker, exhibits weak signals at $5 \mathrm{hmC}$ sites, but much higher signals at $5 \mathrm{fC}$ and $5 \mathrm{caC}$ sites with the highest signals observed at $5 \mathrm{caC}$ sites. These results indicate a gradient of Tet-mediated $5 \mathrm{mC}$ oxidation activity at enhancer sites that is positively correlated with enhancer activity and the extent of hypomethylation. Indeed, when we evaluated the overlap between enhancers and the modification sites, we observed an increased association percentage of these sites within interacting enhancers in the order of $5 \mathrm{caC}>5 \mathrm{fC}$ $>5 \mathrm{hmC}$ (Supplementary information, Figure S1M-S1N). Accordingly, we observed an increased Tet1 occupancy at sites in the order of $5 \mathrm{caC}>5 \mathrm{fC}>5 \mathrm{hmC}$ (Supplementary information, Figure S1O).
Taken together, our results reveal that $5 \mathrm{hmC}, 5 \mathrm{fC}$ and $5 \mathrm{caC}$ mark distinct genomic elements with $5 \mathrm{fC}$ and $5 \mathrm{caC}$ representing more active markers compared to $5 \mathrm{hmC}$. A gradient of $5 \mathrm{hmC}, 5 \mathrm{fC}$ and $5 \mathrm{caC}$ exists in genomic elements, which represents reduced DNA methylation and increased enhancer activity.

We aligned $5 \mathrm{fC}$ and $5 \mathrm{caC}$ sites in $\mathrm{CG}$ context and examined the base compositions (Supplementary information, Figure S1P). On the strand containing 5fCG, we observed higher percentages of cytosine than the strand containing $5 \mathrm{mCG}, 5 \mathrm{hmCG}$ or $5 \mathrm{caCG}$, while $5 \mathrm{caC}$ possesses a similar local sequence context to $5 \mathrm{hmC}$. Within the $100 \mathrm{bp}$ window, we found that thymine composition shows a significant asymmetric distribution for $5 \mathrm{fC}$, indicating that $5 \mathrm{fC}$ and $5 \mathrm{caC}$ locate in different sequence context regions, which may play a functional role in the recruitment of Tet proteins.

We then performed de novo motif analysis with $\mathrm{HO}-$ MER [15] at \pm 100 bp region around the $5 \mathrm{fC}$ and $5 \mathrm{caC}$ sites. Consistent with the previous profiling results [11], we identified the Klf4, Oct4, Hifla, Esrrb, and Sox 2 motifs around the $5 \mathrm{caC}$ sites in $\mathrm{Tdg}^{--}$mouse ESCs (Figure $1 \mathrm{H})$. Using our single-base resolution map, we observed that $5 \mathrm{caC}$ is enriched in the Esrrb-, Klf4-, Oct4-, and Sox2-binding sites, while $5 \mathrm{fC}$ is evenly distributed at lower levels in these regions, suggesting high Tet oxidation activity of these sites (Supplementary information, Figure S1Q). These results indicate that Tet-based $5 \mathrm{mC}$ oxidation activity is the highest at these regions in order to ensure activation of these regulatory elements (Figure 1H).

In summary, we apply a pre-enrichment-based strategy for single-base resolution detection of $5 \mathrm{fC}$ and $5 \mathrm{caC}$ in mouse ESCs. We reveal a genome-wide gradient of $5 \mathrm{mC}$ oxidation activity at regulatory elements, which positively correlates with enhancer activity and negatively correlates with $5 \mathrm{mC}$ abundance (Figure 1I). Both $5 \mathrm{fC}$ and $5 \mathrm{caC}$ mark more active regulatory elements than $5 \mathrm{hmC}$. 
The $5 \mathrm{caC}$ sites represent the most active enhancers among sites with Tet-mediated modifications. At base resolution, $5 \mathrm{fC}$ and $5 \mathrm{caC}$ exhibit very limited overlap, suggesting their distinct roles even though they are all derived from oxidation of $5 \mathrm{mC}$ and $5 \mathrm{hmC}$ and excised by TDG in active demethylation. Our study reveals a highly orchestrated $5 \mathrm{mC}$ and $5 \mathrm{hmC}$ oxidation and demethylation to balance genome-wide methylation/demethylation dynamics in order to accomplish epigenetic regulation at different functional elements.

\section{Acknowledgments}

This work is supported by the National Institutes of Health HG006827 (CH) and CA180657 (LCD), and Howard Hughes Medical Institute $(\mathrm{CH})$. We thank Dr Yi Zhang (Harvard University) for providing the anti-5 caC antibody and Dr Lin Li (Institute of Biochemistry and Cell Biology, SIBS, CAS) for $\mathrm{Tdg}^{-/-}$mESCs. We also thank Reichard SF for editing the manuscript.

Xingyu Lu ${ }^{1, *}$, Dali Han ${ }^{1, *}$, Boxuan Simen Zhao ${ }^{1, *}$, Chun-Xiao Song ${ }^{1}$, Li-Sheng Zhang ${ }^{1}$, Louis C Doré ${ }^{1}$, Chuan $\mathrm{He}^{1}$
${ }^{I}$ Department of Chemistry and Institute for Biophysical Dynamics, Howard Hughes Medical Institute, The University of Chicago, 929 E 57th Street, Chicago, IL 60637, USA

*These three authors contributed equally to this work.

Correspondence: Chuan $\mathrm{He}$

E-mail: chuanhe@uchicago.edu

\section{References}

1 Kriaucionis S, Heintz N. Science 2009; 324:929-930.

2 Tahiliani M, Koh KP, Shen Y, et al. Science 2009; 324:930-935.

3 He YF, Li BZ, Li Z, et al. Science 2011; 333:1303-1307.

4 Ito S, Shen L, Dai Q, et al. Science 2011; 333:1300-1303.

5 Pfaffeneder T, Hackner B, Truss M, et al. Angew Chem Int Ed 2011; 50:7008-7012.

6 Cortázar D, Kunz C, Selfridge J, et al. Nature 2011; 470:419-423.

7 Cortellino S, Xu J, Sannai M, et al. Cell 2011; 146:67-79.

8 Zhang L, Lu X, Lu J, et al. Nat Chem Biol 2012; 8:328-330.

9 Maiti A, Drohat AC. J Biol Chem 2011; 286:35334-35338.

10 Song CX, Szulwach KE, Dai Q, et al. Cell 2013; 153:678-691.

11 Shen L, Wu H, Diep D, et al. Cell 2013; 153:692-706.

12 Raiber EA, Beraldi D, Ficz G, et al. Genome Biol 2012; 13:R69.

13 Lu X, Song CX, Szulwach K, et al. J Am Chem Soc 2013; 135:93159317.

14 Booth MJ, Marsico G, Bachman M, et al. Nat Chem 2014; 6:435-440.

15 Heinz S, Benner C, Spann N, et al. Mol Cell 2010; 38:576-589.

(Supplementary information is linked to the online version of the paper on the Cell Research website.) 